Коротун С. І., к.геогр.н., доцент; Коротун О. П., старший викладач; Власюк О. В., студент 5 курсу (Національний університет водного господарства та природокористування, м. Рівне)

\title{
ПІДСИСТЕМИ ІНФРАСТРУКТУРИ ТУРИСТСЬКОГО БІЗНЕСУ В РІВНЕНСЬКІЙ ОБЛАСТІ
}

В статті наведено підсистеми інфраструктури туристського бізнесу. Розглянуто та охарактеризовано основні підсистеми інфраструктури туристського бізнесу в Рівненській області. Визначено проблеми підсистем та надано загальні рекомендації щодо покращення інфраструктури туристського бізнесу в регіоні.

Ключові слова: інфраструктура, туристський бізнес, підсистеми, Рівненська область.

Актуальність. Невід'ємною частиною світового туристичного процесу $є$ вітчизняна туристична галузь. Попри всі політичні та соціально-економічні негаразди останніх років індустрія туризму стала тією галуззю народного господарства України, яка з року в рік без залучення державних дотацій стабільно нарощує обсяги виробництва туристичного продукту. Туризм в Україні може і повинен стати сферою реалізації ринкових механізмів, джерелом поповнення державного та місцевих бюджетів, засобом загальнодоступного і повноцінного відпочинку та оздоровлення, а також ознайомлення з історико-культурною спадщиною та сьогоденням нашого народу і держави.

Пріоритетним видом туризму для України залишається іноземний (в"їзий) туризм як вагомий чинник поповнення валютними надходженнями державної скарбниці та створення додаткових робочих місць.

Нині Україна має понад 4,5 тис. закладів розміщення туристів і відпочиваючих на 620 тис. місць, але вони потребують модернізації та реконструкції відповідно до міжнародних стандартів. Крім того, підтримання в належному стані потребують і рекреаційні зони, пам'ятки культури та архітектури України, інші об'єкти туристичних чи екскурсійних послуг.

3 урахуванням тенденцій реформування усіх сфер суспільного життя доцільним $є$ розроблення Основних напрямів розвитку туризму в Україні. Вони $\epsilon$ концептуальною базою довгострокової Державної програми розвитку туризму, створення організаційно-правових та економічних засад становлення туризму як високорентабельної 
галузі економіки, важливого засобу культурного та духовного виховання громадян України, відтворення їх трудового потенціалу.

Головним визначником прийому туристів (як зовнішніх, так і внутрішніх) $€$ інфраструктура туристичного бізнесу в регіоні [6], яку можна розглядати в вигляді наступних основних підсистем:

- транспортна підсистема;

- підсистема зв'язку;

- екологічна підсистема;

- рекреаційна підсистема;

- підсистема житлово-комунального господарства;

- освітня підсистема;

- медична підсистема;

- підсистема соціального забезпечення;

- культурна підсистема.

Мета дослідження полягає у виділенні основних підсистем інфраструктури туристичного бізнесу в Рівненській області та надання їм стислої характеристики.

Рівень розвитку інфраструктури Рівненської області в основному забезпечений розвиненою мережею транспортних комунікацій, ділянки яких проходять за напрямками міжнародних європейських доріг, сприяють пропуску транзитних транспортних потоків через регіон, що обумовлює його стратегічне значення у розвитку економіки країни. Розвиток інфраструктури області регламентований «Положенням про управління інфраструктури та промисловості Рівненської обласної державної адміністрації» та «Державною стратегією регіонального розвитку» $[1 ; 2 ; 3 ; 4]$.

Транспортна підсистема. За показником вантажообігу область знаходиться на 10-му місці серед регіонів України та немає тенденції до зростання. За показником пасажирообігу область знаходиться на 11-му місці серед регіонів України та має тенденцію, що коливається. Зростають обсяги перевезень вантажів залізничним транспортом та пасажирів автомобільним транспортом (рис. 1). Мережа автомобільних доріг загального користування Рівненської області станом на 01.01.2017 становить 5143,2 км, з їх числа з твердим покриттям 5072,7 км (або 98,6\%), де: дороги державного значення - 2000,9 км; дороги місцевого значення - 3076,5 км (рис. 2) [5]. В області автобусним сполученням охоплено 98,3\% сільських населених пунктів, це один із кращих показників серед регіонів держави. Це потенційно сприяє розвитку туристичної та туристично-рекреаційної інфраструктури області. 


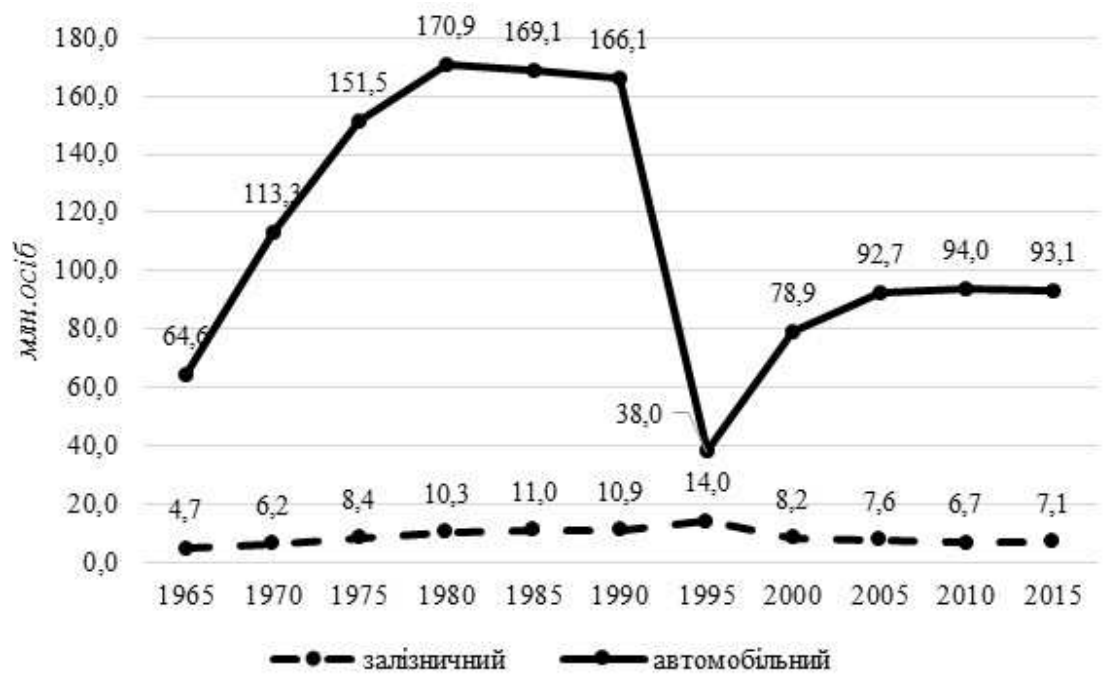

Рис. 1. Перевезення пасажирів за видами транспорту в Рівненській області у 1965-2015 рр.

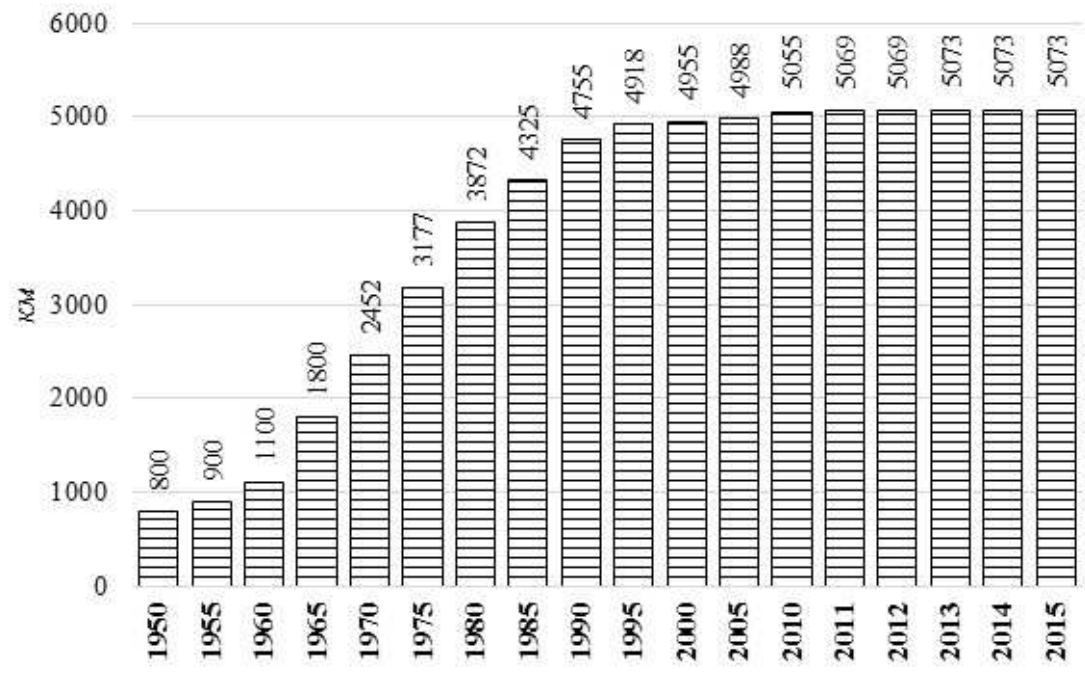

Рис. 2. Довжина автомобільних доріг загального користування з твердим покриттям в Рівненській області у 1950-2015 pр.

Підсистема зв'язку. Тенденція до збільшення щільності зв'язку не спостерігається, оскільки область знаходиться на 21 місці серед регіонів України. В області експлуатуються 471 ATC, загальною монтованою ємністю 224,5 тис. телефонних номерів. Рівень телефонізації на 100 сімей становить 42 телефонні номери [5]. Кількість абонентів мобільного зв'язку становить 1265,65 тис. одиниць, майже кожен житель області. Динамічного розвитку набуває комп'ютерний зв'язок, що пов'язано із підключенням до інформаційної мережі Інтернет все більшої кількості користувачів (станом на 01.01.2017 нара- 
ховувалося 49,4 тис. абонентів, в тому числі 44,2 тис. населення). Рівненська область належить до регіонів, де найнижча щільність мереж фіксованого та мобільного зв'язку в розрахунку на 100 осіб. Перспективним напрямом розвитку інфраструктури зв'язку є розгалуженість мережі Інтернет, на противагу перенасиченості вітчизняного ринку мобільним зв'язком. Динаміка зростання користувачів мобільного зв'язку значно уповільнюється.

Екологічна підсистема. Протягом останніх років техногенне навантаження на навколишнє природне середовище характеризувалося нестабільною динамікою. Рівненська область належить до регіонів, де за звітний період надійшло найменше забруднень від стаціонарних та пересувних джерел (52,2 тис. тонн). Валові обсяги викидів від підприємств області у розрахунку на одну особу - 11-13 кг/особу, що у 9-11 разів менше середніх показників в Україні. Суттєвою складовою забруднення атмосферного повітря області $є$ викиди від пересувних джерел (близько 75\% валових викидів області), які щороку зростають внаслідок збільшення кількості автотранспорту та інтенсивності його руху. В області існують ареали забруднення, зокрема: Рівне, Здолбунів, Рівненський, Здолбунівський та Костопільський район. Згадані території мають близько 60\% викидів шкідливих речовин у повітря, що обумовлюється розташуванням на цій території найбільших підприємств області та значним скупченням автотранспорту. Проблеми підсистеми: модернізація підприємств області у хімічній, деревообробній та промисловій галузях, запуск сміттєпереробного заводу у Рівненському районі.

Рекреаційна підсистема. Перспективна порогова рекреаційна ємність внутрішнього ландшафтного ресурсу складає 1,5 млн осіб відпочиваючих, що дає можливість прийняти на відпочинок відпочиваючих з інших областей України. В області функціонує 30 санаторно-оздоровчих закладів та 46 готелів і мотелів (рис. 3).

В області не сформувалася відповідна до іï рекреаційнотуристичного потенціалу система закладів розміщення. За останнє десятиліття практично відсутні зміни кількості готелів, хоча зростає їх номерний фонд та одноразова місткість. У територіальному розрізі $34 \%$ потужностей готелів розміщені в обласному центрі. Найнижчі показники використання місткості (до 0,1) зафіксовано у північних районах: Зарічненському, Рокитнівському, Костопільському, Березнівському (в середньому в області 0,23). За офіційними даними в області працює близько 90 агросадиб, загальна місткість яких становить близько 400.

У районах, що мають значні природні рекреаційні ресурси та 
недостатній рівень соціально-економічного розвитку та інфраструктурного забезпечення (Березнівський, Зарічненський, Рокитнівський, Сарненський), основна увага має бути приділена розбудові мережі транспортного сполучення та засобів розміщення відпочиваючих, щоб повною мірою реалізувати потенціал природних рекреаційних ресурсів. Разом з тим, в межах таких районів із усіх видів засобів розміщення варто розвивати ті, які придатні для організації природоорієнтованих видів рекреації (бази відпочинку, кемпінги, агросадиби тощо), та еколого-орієнтовані види транспорту для туристів (велосипедний, кінний тощо).

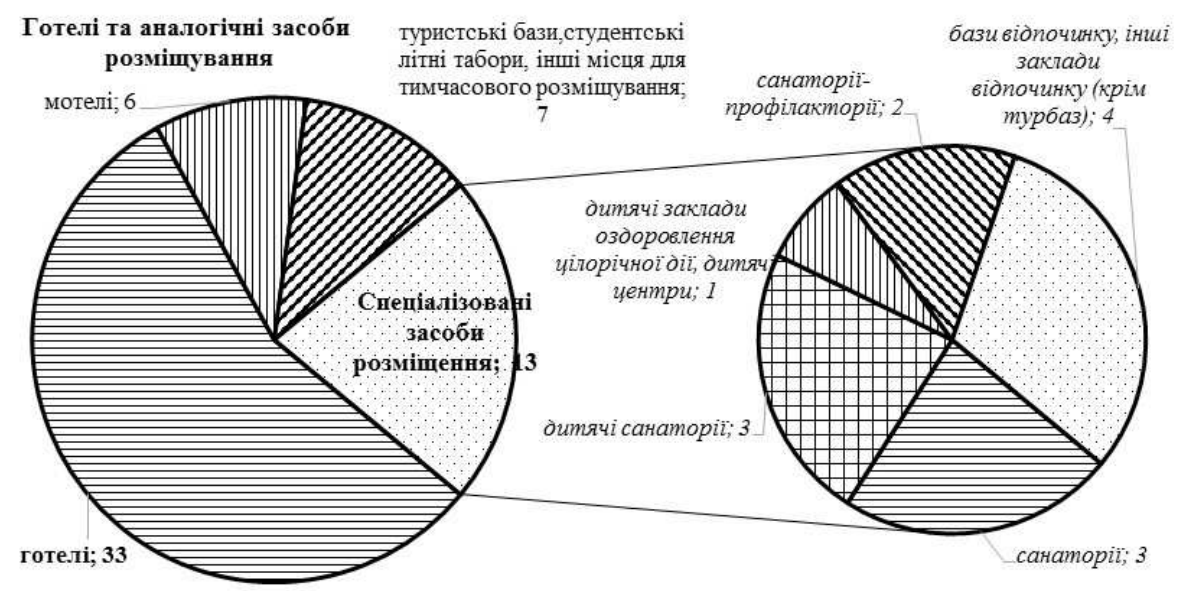

Рис. 3. Колективні засоби розміщування у 2015 році

Підсистема житлово-комунального господарства. Розвиток житлово-комунального господарства у Рівненській області, за напрямом встановлення приладів обліку споживання теплової енергії, відповідає середньостатистичному показнику по Україні. Зокрема, оснащеність будинковими лічильниками тепла складає $25,5 \%$, а лічильників гарячої води - 7,7\% від потреби (по Україні оснащеність будинковими лічильниками тепла становить 26\%, гарячої води 19,9\%). Щорічно зростають обсяги використання альтернативних видів палива на котельнях комунальної теплоенергетики, зокрема у 2013 році використано альтернативного палива 7,1 млн тонн умовного палива, що на $14,3 \%$ більше ніж у 2014 році. До обслуговування житлового фонду залучено 9 приватних підприємств, які обслуговують $3 \%$ загальної кількості багатоквартирних будинків. За темпом зростання обсягів введення в експлуатацію житла область посідає п'яте місце в Україні.

Однією із найбільших проблем у даній підсистемі $\epsilon$ заміна/реконструкція котлів (встановлення котлів з ККД не нижче 91\%) 
та теплових мереж. Разом з тим, із загальної протяжності теплових мереж у незадовільному стані знаходиться 41,7\%, в аварійному $3,1 \%$ (для порівняння по Україні цей показник становить 15,7\%). Зношеність основних фондів підприємств комунальної власності складає 40\%. Житловий фонд області обладнаний 1269 ліфтами, 3 них 878 ліфтів експлуатуються понад 25 років.

В даний час очистка 70\% стічних вод здійснюється на очисних спорудах ПАТ «Рівнеазот» (підприємство недержавної форми власності). Необхідна подальша оптимізація механізмів кредитування ОСББ банками та іншими фінансовими установами, а також залучення приватних підприємств до обслуговування житлового фонду.

Освітня підсистема. Станом на 01.01.2016 в області функціонувало 510 дошкільних та 677 загальноосвітніх навчальних закладів, в яких виховується 37 тис. дітей дошкільного віку та навчається 196,6 тис. учнів. Крім того, в області функціонує 54 комплексних і профільних позашкільних навчальних закладів системи освіти та 2337 гуртків на базі загальноосвітніх навчальних закладів, в яких налічується 93 тис. дітей (66\% загальної кількості). В області функціонує 19 освітніх інтернатних закладів, у яких утримується 2730 вихованців, з них 1478 дітей забезпечені корекційною освітою.

Проблеми підсистеми: Усі загальноосвітні навчальні заклади I-III ступенів області у повному обсязі забезпечені навчальними комп'ютерними комплексами та під'єднані до глобальної мережі Інтернет, що створює додаткові умови для розвитку дистанційного навчання та вирівнювання рівня знань. Реконструкція приміщень дитячих садків, шкіл, покращення їх матеріально-технічної бази. Не усі школи охоплені мережею довозу школярів в рамках Державної програми «Шкільний автобус».

Медична підсистема. У галузі охорони здоров'я: в області функціонує 52 заклади охорони здоров'я (в 2010 році - 75, а в 1995 році - 92), 18 центрів первинної медичної допомоги (до яких входить 623 ФАПи та 156 сільських лікарських амбулаторій загальної практики сімейної медицини), 11 лікарських амбулаторно-поліклінічних закладів, обласний центр невідкладних станів та медицини катастроф (до якого входить 3 станції, 17 підстанцій та 22 пункти постійного базування), 3 санаторії та 11 інших медичних закладів (рис. 4). В сільській місцевості (районах) за принципом сімейності медичну допомогу отримують 96,2\% населення. У закладах охорони здоров'я працює 4311 лікарів, показник забезпеченості становить 37,3 лікаря на 10 тис. населення (при цьому у 11 з 16 районів показник забезпеченості не перевищує 22 лікаря на 10 тис. населення). Внаслідок про- 
веденої оптимізації, ліжковий фонд зменшився за останні 4 роки на 969 ліжок, або на 9,6\%. Більшій половині жителів регіону надається медична допомога на засадах сімейної медицини.

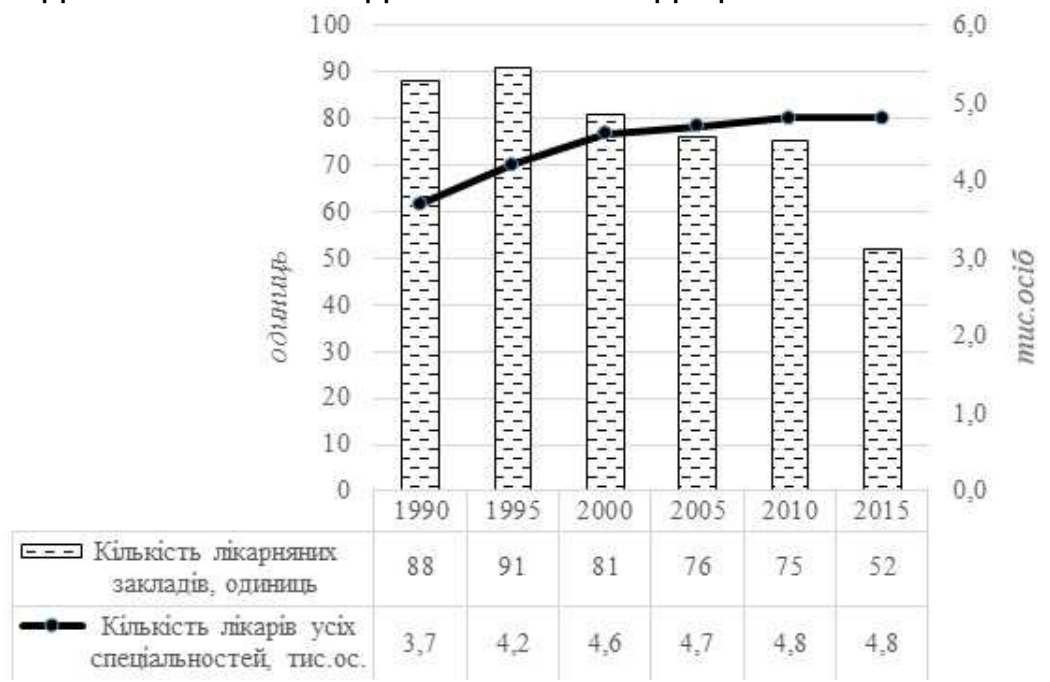

Рис. 4. Мережа та кадри закладів охорони здоров'я

Реорганізація мережі закладів охорони здоров'я та нагальна потреба, за підтримки приватних інвесторів та державних програм, придбання та встановлення сучасного медичного обладнання.

Підсистема соціального забезпечення. Станом на 01.01.2016 в області зареєстровано 1845 дітей-сиріт та дітей, позбавлених батьківського піклування, 3 яких під опікою та піклуванням перебувало 1437 дітей даної категорії. У 2015 році у 64 прийомних сім'ях виховувалось 135 дітей-сиріт та дітей, позбавлених батьківського піклування та 153 дитини зазначеної категорії виховувалось у 22 дитячих будинках сімейного типу. Частка дітей-сиріт і дітей, позбавлених батьківського піклування, які влаштовані до сімейних форм виховання, становить 93\% (один із найвищих по Україні). Впродовж 2012-2015 років в області усиновлено 151 дитину-сироту та дитину, позбавлену батьківського піклування, під опіку та піклування взято 1042 дитини, створено 4 дитячі будинки сімейного типу. В області функціонує 7 інтернатних установ для людей похилого віку та інвалідів, розрахованих на 1210 місць. На початок 2014 року на повному державному утриманні в даних установах проживало 1067 громадян похилого віку та інвалідів, у 2013 році до інтернатних установ направлено 152 інваліди, в тому числі дітей-інвалідів та людей похилого віку. Проблеми підсистеми: недостатня кількість місць у інтернатних закладах освіти та закладах для людей похилого віку та інвалідів, проблема соціалізації дітейсиріт та дітей позбавлених батьківського піклування. 
На основі державних та донорських коштів модернізувати інтернатні заклади освіти і заклади для людей похилого віку та інвалідів. Через співпрацю із громадськими організаціями впровадити систему соціалізації дітей-сиріт та дітей позбавлених батьківського піклування.

Культурна підсистема. Культурно-мистецьке обслуговування населення області здійснюють: 2 обласних театри - академічний український музично-драматичний та ляльковий, обласна філармонія, 575 публічних і публічно-шкільних бібліотек, 673 клуби і будинки культури, 11 державних музеїв і 2 історико-культурні заповідники, в яких зберігається більше 260 тис. експонатів державної частини музейного фонду України, 34 школи естетичного виховання, обласний центр народної творчості, парк культури і відпочинку та зоопарк.

Водночас, відслідковується значна диференціація закладів культури по районах області. Впродовж останніх двадцяти років не проводились необхідні ремонтні та ремонтно-реставраційні роботи на об'єктах галузі, у тому числі пам'ятках архітектури національного значення. Оскільки доступ до Інтернету у сільській місцевості має тільки 108 бібліотек, вкрай важливо впроваджувати сучасні технології комп'ютеризації та підключати бібліотеки до мережі Інтернет.

Висновки. У районах, що мають недостатній рівень соціальноекономічного розвитку та інфраструктурного забезпечення (Березнівський, Зарічненський, Рокитнівський, Сарненський), але володіють значними природними рекреаційними ресурсами, варто розбудовувати мережу транспортного сполучення та засоби розміщення відпочивальників, придатні для організації природо-орієнтованих видів рекреацій (бази відпочинку, кемпінги, агросадиби тощо), та розвивати екологічні маршрути для туристів (велосипедний, кінний тощо). Джерела фінансування: приватні кошти, грантові кошти (програма $\mathrm{OOH}$ «Розвиток, орієнтований на громаду, покращить якість життя в Україні»). Можливий виконавець - громада населеного пункту.

Збільшити кількість точок доступу до мережі Інтернет (область посідає 25 сходинку серед регіонів країни за кількістю абонентів 3 доступом до мережі Інтернет). Джерела фінансування: приватні та державні кошти. Можливий виконавець - підприємці та органи місцевого самоврядування.

1. Положення про управління інфраструктури та промисловості Рівненської обласної державної адміністрації, затверджене Розпорядженням голови Piвненської обласної державної адміністрації від 28.01.2013 № 50. URL: http://www.rv.gov.ua/sitenew/main/ua/publication/content/4859 (дата звер- 
нення : 01.10.2018). 2. Стратегія розвитку Рівненської області на період до 2020 року, затверджено рішенням обласної ради від 18.12.2014 року. № 1374. URL: http://www.rv.gov.ua/sitenew/main/ua/4426.htm (дата звернення : 01.10.2018). 3. Про місцеві державні адміністрації : Закон України від 14.03.2017 р. № 1923-VIII (1923-19), BBP, 2017, № 17. C. 203. 4. Про затвердження Державної стратегії регіонального розвитку на період до 2020 року : постанова Кабінету Міністрів України від 06.08.2014 р. № 385. URL: http://zakon2.rada.gov.ua/laws/show/385-2014-\%D0\%BF (дата звернення : 01.10.2018). 5. Статистичний щорічник Рівненської області за 2016 рік / за ред. Ю. В. Мороз. Рівне : ГУСРО, 2017. 440 с. 6. Федорченко В. К., Дьорова Т. А. Історія туризму в Україні. К. : Вища школа, 2002. 195 с.

\section{REFERENCES :}

1. Polozhennia pro upravlinnia infrastruktury ta promyslovosti Rivnenskoi oblasnoi derzhavnoi administratsii, zatverdzheno Rozporiadzhenniam holovy Rivnenskoi oblasnoi derzhavnoi administratsii vid 28.01.2013 № 50. URL: http://www.rv.gov.ua/sitenew/main/ua/publication/content/4859 (data zvernennia : 01.10.2018). 2. Stratehiia rozvytku Rivnenskoi oblasti na period do 2020 roku, zatverdzheno rishenniam oblasnoi rady vid 18.12 .2014 roku. № 1374. URL: http://www.rv.gov.ua/sitenew/main/ua/4426.htm (data zvernennia : 01.10.2018). 3. Pro mistsevi derzhavni administratsii : Zakon Ukrainy vid 14.03.2017 r. № 1923-VIII (1923-19), VVR, 2017, № 17. S. 203. 4. Pro zatverdzhennia Derzhavnoi stratehii rehionalnoho rozvytku na period do 2020 roku : postanova Kabinetu Ministriv Ukrainy vid 06.08.2014 r. № 385. URL: http://zakon2.rada.gov.ua/laws/show/385-2014-\%D0\%BF (data zvernennia : 01.10.2018). 5. Statystychnyi shchorichnyk Rivnenskoi oblasti za 2016 rik / za red. Yu. V. Moroz. Rivne : HUSRO, 2017. 440 s. 6. Fedorchenko V. K., Dorova T. A. Istoriia turyzmu v Ukraini. K. : Vyshcha shkola, 2002.195 s.

Рецензент: к.е.н., професор Кушнір Н. Б. (НУВГП)

Korotun S. I., Candidate of Geographical Sciences (Ph.D.), Associate Professor; Korotun O. P., Senior Lecturer; Vlasiuk 0. V., Senior Student (National University of Water and Environmental Engineering, Rivne)

\section{SUBSYSTEMS OF TOURIST BUSINESS INFRASTRUCTURE IN THE RIVNE REGION}

The article describes subsystems of tourism business infrastructure. The main subsystems of tourist business infrastructure are described and characterized in the Rivne region. There problems of the 
subsystems are identified and general recommendations for the improvement of the tourism business infrastructure in the region are provided.

Keywords: infrastructure, tourism business, subsystems, Rivne region.

Коротун С. И., к.геогр.н., доцент; Коротун О. П., старший преподаватель; Власюк А. В., студент 5 курса (Национальный университет водного хозяйства и природопользования, г. Ровно)

\section{ПОДСИСТЕМЫ ИНФРАСТРУКТУРЫ ТУРИСТИЧЕСКОГО} БИЗНЕСА В РОВЕНСКОЙ ОБЛАСТИ

В статье представлены подсистемы инфраструктуры туристического бизнеса. Рассмотрены и охарактеризованы основные подсистемы инфраструктуры туристического бизнеса в Ровенской области. Определены проблемы подсистем и предложены общие рекомендации по улучшению инфраструктуры туристического бизнеса в регионе.

Ключевые слова: инфраструктура, туристический бизнес, подсистемы, Ровенская область. 